\title{
Heavy Metals Contamination and Ecological Risk Assessment in Surface Sediments of Namal Lake, Pakistan
}

\author{
Tariq Javed $^{1 *}$, Nasir Ahmad², Azhar Mashiatullah ${ }^{1}$ \\ ${ }^{1}$ Isotope Application Division (IAD), Pakistan Institute of Nuclear Science and Technology (PINSTECH), Nilore, \\ Islamabad, Pakistan \\ ${ }^{2}$ Institute of Geology, University of the Punjab, Lahore 54590, Pakistan
}

Received: 26 March 2017

Accepted: 11 July 2017

\begin{abstract}
Heavy metal concentrations were determined using inductively coupled plasma-optical emission spectrometry (ICP-OES) in surface sediments of Namal Lake, Pakistan. The metals content in sediment varied significantly and were in the order of $\mathrm{Al}>\mathrm{Fe}>\mathrm{Mn}>\mathrm{V}>\mathrm{Zn}>\mathrm{Cr}>\mathrm{Ni}>\mathrm{Cu}>\mathrm{As}>\mathrm{Co}>\mathrm{Pb}>\mathrm{Cd}$. Except for $\mathrm{Al}$, the average concentrations of metals were higher than the average value of the upper continental crust (UCC). The significant positive correlations among heavy metals $(\mathrm{p}<0.01)$ suggested that these metals originated from the same sources. The pollution indices indicated severe contamination of sediments with As, Cd, and $\mathrm{Ni}$. The sediment quality guidelines (SQGs) revealed that $19.2 \%$ of $\mathrm{As}, 11.5 \%$ of $\mathrm{Cr}$, and $88.5 \%$ of $\mathrm{Ni}$ from all the sampling sites exceeded the probable effect level (PEL). The computed average risk index (RI) of single elements were in the following order $\mathrm{Cd}(411.9)>\mathrm{As}(69.0)>\mathrm{Ni}(15.4)>\mathrm{Cu}(10.0)>\mathrm{Cr}(4.3)>$ $\mathrm{Pb}(3.66)>\mathrm{Zn}(1.7)$. Principle component analysis (PCA) extracted three components explaining (76.136\%) of total variance of chemical data and were highly to moderately loaded with $\mathrm{Fe}, \mathrm{Mn}, \mathrm{Co}, \mathrm{Cu}, \mathrm{Zn}, \mathrm{Al}, \mathrm{As}$, $\mathrm{Cd}, \mathrm{Ni}, \mathrm{V}, \mathrm{Cr}, \mathrm{TOC}, \mathrm{pH}, \mathrm{CaCO}_{3}$, and $\mathrm{Pb}$ in three principal components (PCs). The results obtained from cluster analysis, correlation of heavy metals, and principal component analysis suggested the origin of metals from both anthropogenic and natural sources.
\end{abstract}

Keywords: metal pollution indices, enrichment factors, ecological risk index, sediment quality guidelines, multivariate analysis

\section{Introduction}

Heavy metals pollution is a worldwide problem that has grown during the past few decades because of their toxicity, extensive sources, non-biodegradable

*e-mail: javed_t@msn.com, tjaved@pinstech.org.pk characteristics, and accumulative behaviors in aquatic environments [1-3]. These metals are identified as a significant indicator for degradation of aquatic environments. Enormous quantities of metals are being released into the environment both from anthropogenicrelated processes and natural sources through direct discharge into water or indirectly through stormwater runoff, domestic effluents, fossil fuel combustion, and atmospheric depositions [4]. Heavy metals ultimately 
accumulate on the sediment directly during adsorption and sedimentation processes by suspended matters [5-6].

Sediment is habitat for many aquatic organisms and a major reservoir for many of the toxic elements that can migrate back into the water under favorable environmental circumstances. The mobility of metals between the aqueous, particulate, and sediment phases are mainly controlled by $\mathrm{pH}$, redox potential, cation exchange capacity, texture, carbonate, and organic carbon contents [7-10]. Excessive amounts of toxic metals can create severe pollution problems for people and aquatic environments [11]. Therefore, sediments have been extensively used to ascertain sources of contamination and to assess the quality of aquatic environments. It is therefore very important to recognize the distribution of heavy metals in sediments in order to develop plans and approaches for pollution control.

Numerous researchers have previously reported on the distribution of heavy metals, assessment of sediment quality, and computation of pollution load on sediments such as Mighan Lake, USA [12]; Nansihu Lake, China [13]; Dojran Lake, Macedonia [14]; Qaroun Lake, Egypt [15]; Mwanza Lake Victoria [16]; and Dalinouer Lake, China [17]. Determining heavy metal contents and their contamination in sediments leads to enhance the understanding of their behavior in the aquatic environment and is extremely significant for assessing pollution sources [18].

Up-to-date, there is no data available related to heavy metals in surface sediment of Namal Lake. Hence, the present investigation has commenced with the following goals:

1) Determine heavy metals content in surface sediment.

2) Gauge heavy metals contamination using pollution indices.

3) Determine ecological risk using sediment quality guidelines (SQGs).

4) Ascertain the major sources of heavy metals with the help of multivariate statistical methods.

\section{Material and Methods}

\section{Study Area}

Geographically, Namal Lake is situated in Rikhi, a corner of Namal Valley of Mianwali and about $214 \mathrm{~km}$ from Islamabad, Pakistan. The study area is located at $71^{\circ} 48^{\prime} 01.37^{\prime \prime} \mathrm{E}$ and $32^{\circ} 400^{\circ} 54.07^{\prime \prime} \mathrm{N}$, which spreads over an area of $5.5 \mathrm{~km}^{2}$. It is an artificial shallow freshwater lake in the western salt range, and was created during construction of Namal Dam in 1913. Most parts of the lake are less than two meters deep. Average rainfall is about $70-80 \mathrm{~mm}$ for the salt range, with the highest in July and August. Moreover, the lake is fed by various streams that drain from the nearby mountain and it also receives surface runoff from the widespread region of the catchment area. Hill torrents and rain fill Namal Lake throughout the year. The lake is famous for attracting thousands of migratory birds. The untreated domestic agricultural runoffs and contaminants released during recreational events are the main possible causes of pollution in the lake. There are no major industries in the vicinity of the lake except for certain mines. The catchment areas contain plenty of various types of vegetation, which includes subtropical forest and shrubs [19]. Fig. 1 shows the location of Namal Lake and sampling sites.

\section{Sample Collection and Preservation}

Surface sediments were collected from 26 various locations of Namal Lake using a grab sampler in 2012. The sampling locations were selected with the help of a GARMIN III global positioning system (GPS) device as presented in Fig. 1. After sample collection, sediments were immediately transferred into labeled Ziploc polythene plastic bags. The collected sediments were air dried, pulverized to fine powder with the help of a mortar and pestle, and homogenized in a laboratory. The sediment samples were stored in labeled plastic bottles until chemical analyses were carried out. During the processing of sediment samples, special precautions were adopted to avoid cross contamination during sediment samples processing, drying, grinding, sieving, and storage [20].

\section{Sample Preparation and Analysis}

For determining metal concentrations, an accurate weight of 1.00 gram of sediment samples were digested

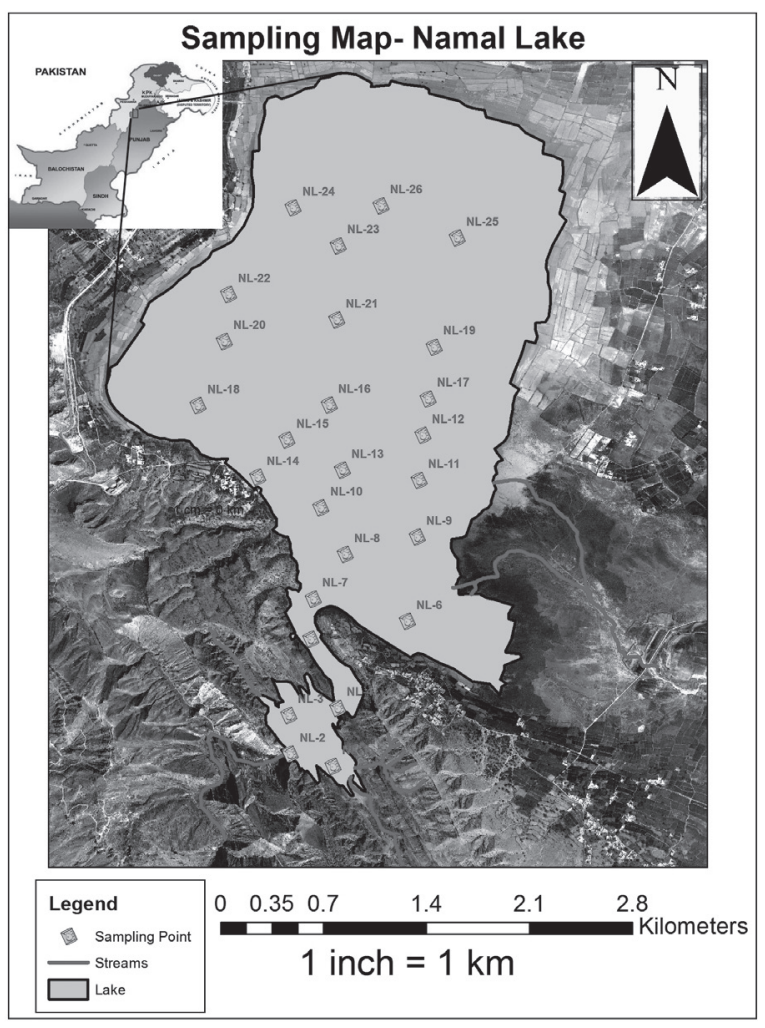

Fig. 1. Location of Namal Lake and sampling sites. 
using a thermostatically controlled Block Digester (Temak-Digestor Model DK 20) with (1:1) $\mathrm{HNO}_{3}, \mathrm{H}_{2} \mathrm{O}_{2}$ $(30 \%)$, and $\mathrm{HCl}$ [21]. The heated samples were then allowed to cool and were filtered using $0.45 \mu \mathrm{m}$ filter paper and finally diluted to $100 \mathrm{ml}$ in a volumetric flask. These samples were transferred to high-quality polyethylene bottles and stored at $4^{\circ} \mathrm{C}$. Metals such as $\mathrm{Al}, \mathrm{As}, \mathrm{Cd}$, $\mathrm{Co}, \mathrm{Cr}, \mathrm{Cu}, \mathrm{Fe}, \mathrm{Mn}, \mathrm{Ni}, \mathrm{Pb}, \mathrm{V}$, and $\mathrm{Zn}$ were analyzed using an inductively coupled plasma-optical emission spectrometer (Model iCAP6500, Thermo Fisher, UK) equipped with iTEVA analyst software at the Central Analytical Facility Division (CAFD) for simultaneous measurements of all elements of interest. The accuracy and analytical precision of the method was assessed by comparing the metal contents in certified reference material (Soil-5, IAEA standard) with the measured values and the percentage recoveries of metals from certified reference material: Fe (82.93\%), Pb (89.6\%),

Table 1. Concentrations and statistical summaries of heavy metals, $\mathrm{TOC}, \mathrm{CaCO}_{3}$, and $\mathrm{pH}$ of surface sediments $(\mathrm{n}=26)$.

\begin{tabular}{|c|c|c|c|c|c|c|c|c|c|c|c|c|c|c|c|}
\hline Locations & $\mathrm{Al}$ & As & $\mathrm{Cd}$ & $\mathrm{Co}$ & $\mathrm{Cr}$ & $\mathrm{Cu}$ & $\mathrm{Fe}$ & $\mathrm{Mn}$ & Ni & $\mathrm{Pb}$ & $\mathrm{V}$ & $\mathrm{Zn}$ & $\mathrm{pH}$ & TOC & $\mathrm{CaCO}_{3}$ \\
\hline & \multicolumn{12}{|c|}{$\mathrm{mg} \mathrm{kg}^{-1}$} & & \multicolumn{2}{|c|}{$\%$} \\
\hline NL-1 & 41,636 & 13.34 & 1.76 & 14.00 & 104.0 & 26.54 & 40,681 & 474 & 72.0 & 15.56 & 84.3 & 79.0 & 7.67 & 1.65 & 35.74 \\
\hline NL-2 & 45,516 & 12.54 & 1.45 & 15.20 & 73.45 & 25.56 & 27,267 & 482 & 56.0 & 12.38 & 153.6 & 76.0 & 7.66 & 0.61 & 44.75 \\
\hline NL-3 & 43,826 & 17.26 & 1.54 & 14.00 & 69.00 & 24.00 & 26,112 & 489 & 49.0 & 11.50 & 146.6 & 74.7 & 7.60 & 1.91 & 33.49 \\
\hline NL-4 & 43,679 & 20.38 & 1.76 & 14.40 & 67.87 & 24.00 & 26,461 & 484 & 53.0 & 11.29 & 148.0 & 72.3 & 7.76 & 0.87 & 42.50 \\
\hline NL-5 & 44,332 & 30.90 & 1.56 & 14.00 & 68.00 & 25.39 & 24,877 & 450 & 39.0 & 12.48 & 147.3 & 78.7 & 7.72 & 1.65 & 35.74 \\
\hline NL-6 & 46,964 & 18.65 & 1.00 & 15.38 & 72.00 & 27.00 & 29,638 & 549 & 48.0 & 12.20 & 156.9 & 81.0 & 7.67 & 0.87 & 42.50 \\
\hline NL-7 & 47,089 & 20.67 & 1.98 & 15.00 & 70.65 & 27.90 & 29,016 & 514 & 48.0 & 11.30 & 153.4 & 81.6 & 7.63 & 0.61 & 44.75 \\
\hline NL-8 & 51,842 & 11.45 & 2.78 & 19.00 & 84.00 & 39.00 & 37,921 & 660 & 57.0 & 15.80 & 157.6 & 133.0 & 7.79 & 0.35 & 47.00 \\
\hline NL-9 & 46,947 & 11.23 & 2.00 & 18.65 & 80.67 & 33.00 & 35,562 & 599 & 36.0 & 12.00 & 157.0 & 110.4 & 7.84 & 0.61 & 44.75 \\
\hline NL-10 & 44,610 & 13.26 & 1.98 & 17.00 & 78.45 & 29.00 & 32,925 & 568 & 30.0 & 11.50 & 158.5 & 103.7 & 7.50 & 0.61 & 44.75 \\
\hline NL-11 & 45,273 & 10.56 & 1.00 & 16.90 & 76.00 & 28.00 & 32,305 & 532 & 47.0 & 12.49 & 156.0 & 99.4 & 7.65 & 0.65 & 50.00 \\
\hline NL-12 & 52,147 & 13.29 & 1.00 & 18.65 & 17.00 & 46.70 & 34,020 & 589 & 58.0 & 10.76 & 168.5 & 115.3 & 7.65 & 0.35 & 47.00 \\
\hline NL-13 & 45,586 & 12.49 & 1.67 & 15.00 & 72.00 & 28.78 & 30,877 & 513 & 51.0 & 9.90 & 159.0 & 114.2 & 7.45 & 0.87 & 42.50 \\
\hline NL-14 & 42,515 & 15.89 & 1.00 & 15.00 & 68.00 & 25.00 & 29,451 & 505 & 53.0 & 11.70 & 150.6 & 88.6 & 7.65 & 0.84 & 42.50 \\
\hline NL-15 & 46,145 & 11.87 & 1.65 & 17.00 & 77.00 & 29.00 & 33,062 & 551 & 52.0 & 10.10 & 159.0 & 104.0 & 7.78 & 1.20 & 38.80 \\
\hline NL-16 & 52,485 & 13.78 & 2.00 & 19.43 & 84.00 & 41.00 & 36,534 & 587 & 17.0 & 14.29 & 173.5 & 115.0 & 7.63 & 0.80 & 42.60 \\
\hline NL-17 & 50,815 & 10.45 & 1.67 & 19.00 & 93.00 & 33.00 & 37,592 & 622 & 59.0 & 11.34 & 171.0 & 109.9 & 7.99 & 1.90 & 39.30 \\
\hline NL-18 & 33,151 & 15.98 & 1.00 & 14.00 & 64.00 & 23.56 & 26,294 & 547 & 18.0 & 9.00 & 116.2 & 89.5 & 7.98 & 0.97 & 48.23 \\
\hline NL-19 & 41,211 & 14.78 & 1.76 & 15.39 & 78.00 & 26.00 & 30,728 & 553 & 51.0 & 15.50 & 144.0 & 98.0 & 7.56 & 0.80 & 45.40 \\
\hline NL-20 & 30,735 & 9.89 & 0.95 & 15.92 & 85.09 & 26.39 & 34,010 & 531 & 82.7 & 14.11 & 63.5 & 83.2 & 7.87 & 1.47 & 36.20 \\
\hline NL-21 & 26,081 & 8.47 & 0.70 & 13.16 & 67.04 & 23.87 & 28,565 & 414 & 81.9 & 11.40 & 49.6 & 66.8 & 7.90 & 0.67 & 40.43 \\
\hline NL-22 & 41,001 & 14.39 & 1.00 & 19.72 & 114.40 & 35.39 & 42,883 & 658 & 116.0 & 17.24 & 74.0 & 98.8 & 8.10 & 0.46 & 42.01 \\
\hline NL-23 & 30,237 & 9.94 & 0.80 & 14.60 & 86.20 & 24.62 & 32,816 & 472 & 88.4 & 13.94 & 60.7 & 74.6 & 7.85 & 0.79 & 38.76 \\
\hline NL-24 & 20,539 & 8.32 & 0.79 & 12.84 & 53.10 & 18.51 & 25,436 & 499 & 55.4 & 9.38 & 46.8 & 61.9 & 8.02 & 0.58 & 41.05 \\
\hline NL-25 & 31,581 & 10.46 & 0.85 & 15.85 & 79.68 & 28.89 & 35,347 & 473 & 78.1 & 14.24 & 62.3 & 80.8 & 7.81 & 0.80 & 42.15 \\
\hline NL-26 & 26,515 & 8.53 & 0.76 & 15.26 & 83.90 & 23.68 & 31,801 & 521 & 93.6 & 12.11 & 59.0 & 74.0 & 7.98 & 0.68 & 38.70 \\
\hline Min. & $20,538.5$ & 8.3 & 0.7 & 12.78 & 17.0 & 18.5 & $24,877.0$ & 413.6 & 17.0 & 9.0 & 46.8 & 61.9 & 7.45 & 0.35 & 33.49 \\
\hline Max. & $52,485.0$ & 30.9 & 2.8 & 19.7 & 114.4 & 46.7 & $42,882.7$ & 660.0 & 116.0 & 17.2 & 173.5 & 133.0 & 8.10 & 1.91 & 50.0 \\
\hline Average & $41,248.3$ & 13.8 & 1.4 & 15.9 & 75.6 & 28.6 & $32,006.9$ & 532.1 & 57.3 & 12.4 & 126.0 & 90.9 & 7.76 & 0.91 & 41.98 \\
\hline Stdev. & $8,780.1$ & 4.9 & 0.5 & 2.0 & 17.3 & 6.2 & $4,755.1$ & 61.4 & 22.7 & 2.1 & 44.9 & 18.1 & 0.17 & 0.45 & 4.11 \\
\hline $\mathrm{UCC}[25]$ & 77,440 & 2.0 & 0.103 & 11.6 & 35.0 & 14.3 & 30,890 & 527 & 18.6 & 17 & 53 & 52 & - & - & - \\
\hline
\end{tabular}


$\mathrm{Cd}$ (95.4\%), $\mathrm{Cu}$ (94.3\%), Zn (5.6\%), Ni (83.7\%), and $\mathrm{Cr}$ $(80.6 \%)$. All chemicals and analytical reagents used in the present investigation were of analytical grade (Scharlau, Spain). The analytical results were within certified values and presented in $\mathrm{mg} \mathrm{kg}^{-1}$ dry weight (dw). The total organic carbon and calcium carbonate contents in sediments were analyzed using the procedure as mentioned [22-23]. The $\mathrm{pH}$ of sediments was measured in sediment to deionized water by the ratio 1:5.0 (sediment:water) [24] with a $\mathrm{pH}$ meter (Model Crison, France). Before measurement, the $\mathrm{pH}$ meter was calibrated with standard $\mathrm{pH}$ buffers of 7.00, 4.00 , and 9.2 .

\section{Statistical Analyses}

Statistical analysis was performed on geochemical data using IBM SPSS-20 for Windows (IBM Corporation, Armonk, USA). Pearson's correlation coefficient analysis in a two-tailed test $(0.01$ and 0.05$)$, and cluster analysis (CA) and principal component analysis (PCA) were used to determine correlations among the metals. In the present study, Kaiser Meyr Olkin (KMO) and Bartlett's test were applied to evaluate the validity of principal component analysis (PCA).

\section{Results and Discussion}

\section{Heavy Metal Concentrations in Surface Sediments}

The ranges and the mean concentrations of heavy metals (HMs), pH, total organic carbon, and calcium carbonate in surface sediments $(n=26)$ of Namal Lake are summarized in Table 1. The average concentrations of metals in the upper continental crust (UCC) for surface sediment are also mentioned for comparison [25]. It is reported that the organic matter (OM) in an aquatic environment has been found to be a key role in controlling physico-chemical behaviors of metals between interfaces of sediments-water, and can considerably influence the bio-availability and mobility of metals in sediments [26]. In the present investigation, total organic carbon (TOC) in sediment fluctuated in the range $0.35-1.91 \%$, with average value of $0.91 \%$. The highest TOC content is recorded at the sampling locations (NL-3). In general, the minor enrichment of organic carbon in the surface layer of sediment suggests the incorporation of organic matter transported from the surrounding area to a lake during the rainy season [27-28]. The TOC content in surface sediment is basically a prime source of food for benthic organisms and is therefore an important structuring factor for the composition of benthic organisms [29]. Comparable values of TOC were found in surface sediments [30]. However, calcium carbonate in sediment ranged $33.49-50.0 \%$, with average value of $41.98 \%$. The exposed salt rocks in surrounding hilly areas dissolve in the water on rainy occasions and form precipitates/ deposits on sediment surface [31]. The $\mathrm{pH}$ values of surface sediment ranged 7.45-8.10 with average value of 7.74 , and are neutral to slightly basic in nature.

In addition, the heavy metal concentrations are also compared with reference values of upper continental crust (UCC). Among the 12 metals studied, average concentrations $\left(\mathrm{mg} \mathrm{kg}{ }^{-1}\right)$ of $\mathrm{Fe}(32,006.9)$, As (13.8), Cd (1.4), Co (15.9), Cr (75.6), Cu (28.6), Mn (532.1), $\mathrm{Ni}$ (57.3), Pb (12.4), V (126.0), and Zn (90.9) exceeded the mean values of the upper continental crust except for Al (41,248.3), and varied substantially in surface sediments. This revealed that the lake is endangered by anthropogenic sources of pollution related to domestic waste and agricultural runoff. Aluminum and Iron metals are most abundantly found in the sediment and ranged 20,538.5-52,485.0 mg kg-1 and $24,877-42,883 \mathrm{mg} \mathrm{kg}^{-1}$, respectively (Table 1). The elevated contents of iron in sediment are due to the transport of iron minerals, which are produced during weathering of soil/rocks and ultimately settle down in Namal Lake in the form of insoluble oxides [32]. Thus the concentration of iron and aluminum in surface sediment of a lake can play an important role in the adsorption/scavenging of heavy metals on the surface of oxides and hydroxides of iron and aluminum, and may regenerate into a water column during environmental changes. Aluminum is the main component of silicate minerals and might originate from the weathering of parent rock bedrock [33-35]. The abundance of average concentrations of these metals are in order $\mathrm{Al}>\mathrm{Fe}>\mathrm{Mn}>\mathrm{V}>\mathrm{Zn}>\mathrm{Cr}>\mathrm{Ni}>\mathrm{Cu}>\mathrm{As}>\mathrm{Co}>\mathrm{Pb}>\mathrm{Cd}$.

The magnitude of heavy metals such as As (4.215.5), Cd (15.5-27.2), Co (1.1-1.7), Cr (0.5-3.3), Cu (1.33.3), Fe (0.8-1.4), Mn (0.8-1.3), Ni (0.9-6.2), Pb (0.5-1.0), $\mathrm{V}$ (0.9-3.3), and Zn (1.2-2.6) fold higher than UCC [36]. The elevated concentrations of arsenic at location NL-4 and nickel (NL-22) revealed the inputs of fertilizers, agricultural runoff, and natural sources of pollution from the surrounding area. The concentrations of cobalt are slightly higher than the background level. The significant higher concentration of $\mathrm{As}, \mathrm{Cd}, \mathrm{Ni}, \mathrm{Cr}$, and $\mathrm{Cu}$ might be due to anthropogenic activities such as agricultural runoff and domestic waste. However, the concentrations of $\mathrm{Zn}, \mathrm{Pb}, \mathrm{Co}, \mathrm{Fe}$, and $\mathrm{Co}$ in sediment are comparable to UCC levels. Although nickel is an essential trace metal, it can be toxic to aquatic life at elevated concentrations [37].

\section{Pearson's Correlation Coefficient Analysis}

Correlation analysis provides an effective way to find relationships among various variables to know the factors and sources of chemical constituents in environmental pollution studies. Heavy metals in sediments are controlled by innumerable factors that include the concentration of metals in rocks at the time of formation of sediments and anthropogenic sources of pollution [38-42]. The results of Pearson's correlation coefficients and their significance levels $(\mathrm{P}<0.01$ and $\mathrm{P}<0.05)$ are shown in Table 2 . The significant strong positive correlations between heavy metals like $\mathrm{Al} / \mathrm{Mn}(0.515, \mathrm{p}<0.01), \mathrm{Al} / \mathrm{Cd}(0.668, \mathrm{p}<0.01)$, $\mathrm{Al} / \mathrm{Co}(0.61, \mathrm{p}<0.01), \mathrm{Al} / \mathrm{Cu}(0.668, \mathrm{p}<0.01), \mathrm{Al} / \mathrm{V}(0.913$, 
Table 2. Pearson's correlation coefficients between heavy metals, $\mathrm{TOC}, \mathrm{CaCO}_{3}$, and $\mathrm{pH}$ in surface sediments of Namal Lake.

\begin{tabular}{|c|c|c|c|c|c|c|c|c|c|c|c|c|c|c|c|}
\hline Variables & $\mathrm{Al}$ & $\mathrm{Fe}$ & $\mathrm{Mn}$ & As & $\mathrm{Cd}$ & Co & $\mathrm{Cr}$ & $\mathrm{Cu}$ & $\mathrm{Ni}$ & $\mathrm{Pb}$ & $\mathrm{V}$ & $\mathrm{Zn}$ & TOC & $\mathrm{CaCO}_{3}$ & $\mathrm{pH}$ \\
\hline $\mathrm{Al}$ & 1 & .273 & $.515^{* *}$ & .377 & $.696^{* *}$ & $.610^{* * *}$ & -.019 & $.668^{* *}$ & $-.466^{*}$ & .100 & $.913^{* *}$ & $.703^{* * *}$ & .055 & .285 & $-.538^{* * *}$ \\
\hline $\mathrm{Fe}$ & & 1 & $.616^{* * *}$ & $-.401^{*}$ & .223 & $.735^{* *}$ & $.597^{* *}$ & $.631^{* *}$ & $.393^{*}$ & $.661^{* *}$ & -.065 & $.555^{* * *}$ & -.072 & .022 & .188 \\
\hline $\mathrm{Mn}$ & & & 1 & -.171 & $.412^{*}$ & $.873^{* * *}$ & .219 & $.704^{* *}$ & -.079 & .274 & $.391^{*}$ & $.798^{* * *}$ & -.250 & $.407^{*}$ & .168 \\
\hline As & & & & 1 & .259 & -.206 & -.146 & -.074 & -.373 & -.047 & $.415^{*}$ & -.128 & .287 & -.125 & -.318 \\
\hline $\mathrm{Cd}$ & & & & & 1 & .381 & .204 & .379 & $-.476^{*}$ & .183 & $.643^{* *}$ & $.586^{* * *}$ & .058 & .146 & $-.427^{*}$ \\
\hline $\mathrm{Co}$ & & & & & & 1 & .240 & $.865^{\text {** }}$ & -.010 & .372 & $.418^{*}$ & $.821^{* * *}$ & -.242 & .342 & .070 \\
\hline $\mathrm{Cr}$ & & & & & & & 1 & -.080 & .381 & $.650^{* *}$ & -.233 & .056 & .243 & -.293 & .251 \\
\hline $\mathrm{Cu}$ & & & & & & & & 1 & -.084 & .298 & $.451^{*}$ & $.809^{* * *}$ & -.278 & .347 & -.125 \\
\hline $\mathrm{Ni}$ & & & & & & & & & 1 & $.466^{*}$ & $-.704^{* * *}$ & -.304 & -.073 & -.361 & $.497^{* * *}$ \\
\hline $\mathrm{Pb}$ & & & & & & & & & & 1 & -.213 & .166 & -.058 & -.096 & .059 \\
\hline V & & & & & & & & & & & 1 & $.615^{* *}$ & .050 & .374 & $-.614^{* * *}$ \\
\hline $\mathrm{Zn}$ & & & & & & & & & & & & 1 & -.207 & $.463^{*}$ & -.240 \\
\hline TOC & & & & & & & & & & & & & 1 & $-.737^{* *}$ & -.016 \\
\hline $\mathrm{CaCO}_{3}$ & & & & & & & & & & & & & & 1 & -.154 \\
\hline $\mathrm{pH}$ & & & & & & & & & & & & & & & 1 \\
\hline
\end{tabular}

**Correlation is significant at the 0.01 level (two-tailed)

*Correlation is significant at the 0.05 level (two-tailed).

$\mathrm{p}<0.01), \mathrm{Al} / \mathrm{Zn}(0.703, \mathrm{p}<0.01), \mathrm{Cd} / \mathrm{V}(0.643, \mathrm{p}<0.01), \mathrm{Cd} /$ $\mathrm{Zn}(0.586, \mathrm{p}<0.01), \mathrm{Co} / \mathrm{Cu}(0.865, \mathrm{p}<0.01), \mathrm{Co} / \mathrm{Zn}(0.821$, $\mathrm{p}<0.01), \mathrm{Cr} / \mathrm{Pb}(0.650, \mathrm{p}<0.01), \mathrm{Cu} / \mathrm{Zn}(0.809, \mathrm{p}<0.01)$, and $\mathrm{V} / \mathrm{Zn}(0.615, \mathrm{p}<0.01)$ in Namal Lake sediments indicates that these metals originated from the same sources or were distributed in the surface by the same physico-chemical processes [43-44]. The higher correlation between Al and $\mathrm{Cu}$ is probably due to having the same source along with their chemical affinity. Natural sources of $\mathrm{Cu}$ in the environment are weathering processes, plant decay, and domestic waste [45].

The correlations of $\mathrm{Fe}$ and $\mathrm{Mn}$ with heavy metals, which includes $\mathrm{Co} / \mathrm{Fe}(\mathrm{r}=0.735, \mathrm{p}<0.01), \mathrm{Cr} / \mathrm{Fe}(\mathrm{r}=0.597$, $\mathrm{p}<0.01) \mathrm{Co} / \mathrm{Mn}(\mathrm{r}=0.873, \mathrm{p}<0.01), \mathrm{Zn} / \mathrm{Mn}(\mathrm{r}=0.798$, $\mathrm{p}<0.01), \mathrm{Fe} / \mathrm{Mn}(\mathrm{r}=0.616, \mathrm{p}<0.01)$ can be interpreted as mainly due to the association of heavy metals on oxides and hydroxides of Mn and Fe [33]. Low positive (Table 2) correlations between metals also demonstrate that they are originating from multiple sources or have different chemical behavior in the lake bed [46]. The correlations are also computed between heavy metals and $\mathrm{pH}$, TOC, and $\mathrm{CaCO}_{3}$ content. Although the weak or lack of significant correlations between heavy metals and TOC shows that heavy metals are not controlled by organic carbon content [30], there is significant strong negative correlation between $\mathrm{TOC}$ and $\mathrm{CaCO}_{3}$, indicating the dominance of calcium carbonate content in sediments. The significant negative correlation between $\mathrm{pH}$ and metals is also observed. The presence of correlations in the sediment may create high ecological risk to aquatic life.
Metal Pollution Indices

Pollution indices can be a helpful tool for assessing sediment contamination and have been extensively used by numerous researchers to gauge sediment pollution [37, 45-46]. In the present study, upper continental crust [25] as a background was used to assess metals pollution in sediments.

\section{Enrichment Factor (EF)}

Enrichment factor (EF) differentiates the influence of anthropogenic contributions from natural factors on metal variations in the sediment [2]. In the present study, $\mathrm{Al}$ is the main component of clay mineral [45] and has been used to normalize geochemical data due to its conservative behavior [47-48]. The following relationship is used to calculate the enrichment factor (EF) [14]:

$$
\text { Enrichment Factor }=\left[\frac{(\mathrm{Cn} / \mathrm{Al})_{\text {Sample }}}{(\mathrm{Cn} / \mathrm{Al})_{\text {Background }}}\right]
$$

...where Cn represents the concentration of " $n$ " element, $(\mathrm{Cn} / \mathrm{Al})_{\text {sample }}$ is the ratio of metal and $\mathrm{Al}$ content in the sample, and $(\mathrm{Cn} / \mathrm{Al})_{\text {background }}$ is the ratio of metal and $\mathrm{Al}$ content in the upper continental crust (UCC). According to enrichment classification [49], $\mathrm{EF}<1$ indicates "no enrichment," $\mathrm{EF}<3$ "minor enrichment," $3 \leq \mathrm{EF} \leq 5$ "moderate enrichment," $5 \leq \mathrm{EF} \leq 10$ "moderately severe 
Table 3. Enrichment factor (EF), geo-accumulation Index $\left(\mathrm{I}_{\text {geo }}\right)$, contamination factor $(\mathrm{Cf})$, and degree of contamination $(\mathrm{Cd})$ of Namal Lake with respect to the Upper Continental Crust.

\begin{tabular}{|c|c|c|c|c|c|c|c|c|c|c|c|c|c|c|c|c|}
\hline & $\mathrm{Al}$ & $\mathrm{As}$ & $\mathrm{Cd}$ & $\mathrm{Co}$ & $\mathrm{Cr}$ & $\mathrm{Cu}$ & $\mathrm{Fe}$ & $\mathrm{Mn}$ & $\mathrm{Ni}$ & $\mathrm{Pb}$ & $\mathrm{V}$ & $\mathrm{Zn}$ & \\
\hline \multicolumn{10}{|c|}{ Enrichment Factors (EF) } \\
\hline Min. & 1.00 & 7.96 & 14.56 & 2.11 & 0.72 & 2.97 & 1.41 & 1.49 & 1.35 & 0.94 & 2.64 & 2.47 & \\
\hline Max. & 1.00 & 26.99 & 40.71 & 4.17 & 7.00 & 4.96 & 3.10 & 3.57 & 14.7 & 2.10 & 5.19 & 4.49 & \\
\hline Average & 1.00 & 13.15 & 25.47 & 2.68 & 4.28 & 3.84 & 2.04 & 1.98 & 6.40 & 1.44 & 4.33 & 3.36 & \\
\hline \multicolumn{10}{|c|}{ Geo-accumulation Index (Igeo) } \\
\hline Min & -2.50 & 1.47 & 2.19 & -0.44 & -1.63 & -0.21 & -0.90 & -0.93 & -0.71 & -1.50 & -0.76 & -0.33 & \\
\hline Max & -1.15 & 3.36 & 4.18 & 0.18 & 1.12 & 1.12 & -0.11 & -0.26 & 2.06 & -0.56 & 1.13 & 0.77 & \\
\hline Average & -1.53 & 2.13 & 3.09 & -0.14 & 0.47 & 0.39 & -0.55 & -0.58 & 0.92 & -1.05 & 0.54 & 0.19 & \\
\hline \multicolumn{10}{|c|}{ Contamination factor (Cf) } & & & \multicolumn{1}{|c|}{} \\
\hline Min & 0.27 & 4.16 & 6.86 & 1.11 & 0.49 & 1.29 & 0.78 & 0.78 & 0.91 & 0.53 & 0.88 & 1.19 & 19.3 \\
\hline Max & 0.68 & 15.45 & 27.25 & 1.70 & 3.27 & 3.27 & 1.39 & 1.25 & 6.24 & 1.01 & 3.27 & 2.56 & 67.3 \\
\hline Average & 0.53 & 6.90 & 13.73 & 1.37 & 2.16 & 2.00 & 1.04 & 1.01 & 3.08 & 0.73 & 2.38 & 1.75 & 36.7 \\
\hline
\end{tabular}

enrichment," $10 \leq \mathrm{EF} \leq 25$ "severe enrichment," $25 \leq \mathrm{EF} \leq 50$ "very severe enrichment," and EF>50 "extremely severe enrichment". The enrichment factors of studied elements in surface sediments of Namal Lake are shown in Table 3 and Fig. 2. The significant variations in enrichment factors of Cd (14.56-40.71), As (7.96-26.99), $\mathrm{Ni}$ (1.35-14.7), $\mathrm{Cr}(0.72-7.0), \mathrm{V}(2.64-5.19), \mathrm{Cu}(2.97-4.96), \mathrm{Zn}(2.47-4.49)$, Co (2.11-4.17), Fe (1.41-3.10), Mn (1.49-3.57), and $\mathrm{Pb}$ (0.94-2.10) were observed in the studied area. Based on the average values of EF, As (13.15) and Cd (25.47) showed severe enrichment $(\mathrm{EF}=10-25)$; Ni (6.40) moderately severe enrichment (5-10); $\mathrm{Cr}$ (4.28), $\mathrm{Cu}$ (3.84), $\mathrm{V}(4.33), \mathrm{Pb}$ (1.44), and $\mathrm{Zn}$ (3.36) moderate enrichment $(\mathrm{EF}=3-5)$; and Co (2.68), Fe (2.04), and Mn (1.98) minor enrichment $(\mathrm{EF}<3)$ in the studied area [12].

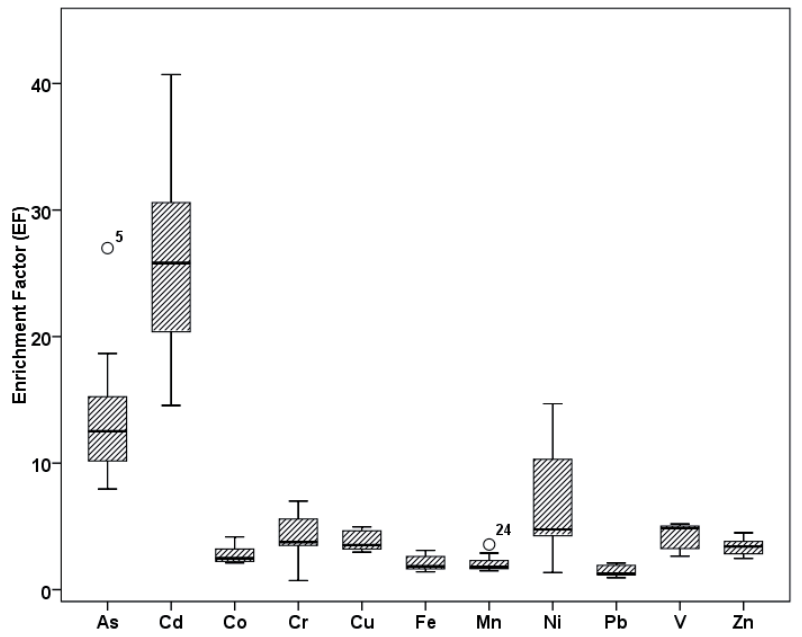

Fig. 2. Enrichment factor (EF) of heavy metals plotted in box and whisker method (rectangle-enrichment of metals; central line of each plot-median) of the surface sediments of Namal Lake.
According to classification [49], the interpretations for $\mathrm{Cd}, \mathrm{As}, \mathrm{Ni}, \mathrm{Cr}, \mathrm{V}, \mathrm{Cu}$, and $\mathrm{Zn}$ are described as anthropogenic and natural sources of contamination. However, $\mathrm{Co}, \mathrm{Fe}, \mathrm{Mn}$, and $\mathrm{Pb}$ with minor enrichment are due to natural sources. The potential sources of these heavy metals in bottom sediment are the contribution of discharges from domestic wastes and agriculture runoff from catchment areas into the lake. Comparable values of $\mathrm{EF}$ for $\mathrm{Ni}$ and $\mathrm{Cr}$ have also been mentioned in [50]. Sewage waste, which contains various species of bacteria, can also support the partitioning of $\mathrm{Cd}$ metal between water and sediments [51]. The higher $\mathrm{EF}$ for arsenic in sediments is indicative of the use of pesticides in agricultural land and geogenic sources of contamination.

\section{Geo-Accumulation Index (Igeo)}

Geo-accumulation index (Igeo) is another tool for assessing the enrichment of metal contents in sediment above baseline concentrations [52]:

$$
I_{\text {geo }}=\log _{2}\left(\frac{C_{n}}{1.5 B_{n}}\right)
$$

...where $\mathrm{C}_{\mathrm{n}}$ is metal concentration of $\mathrm{n}$ element in sediment sample and $\mathrm{B}_{\mathrm{n}}$ is the geochemical background values of metal (n). The constant 1.5 is the background matrix correction factor due to lithogenics. The classification of geo-accumulation index [53] indicates: class 0 (Igeo $\leq 0)$ unpolluted, class $1 \quad(0<$ Igeo $<1)$ uncontaminated to moderately contaminated, class $2(1<$ Igeo $<2)$ moderately contaminated, class $3(2<$ Igeo $<3)$ moderately to strongly polluted, class $4(3<$ Igeo $<4)$ strongly polluted, class 5 $(4<$ Igeo $<5)$ strongly to extremely polluted, and class 6 (5>Igeo) extremely polluted. Very strong contamination 


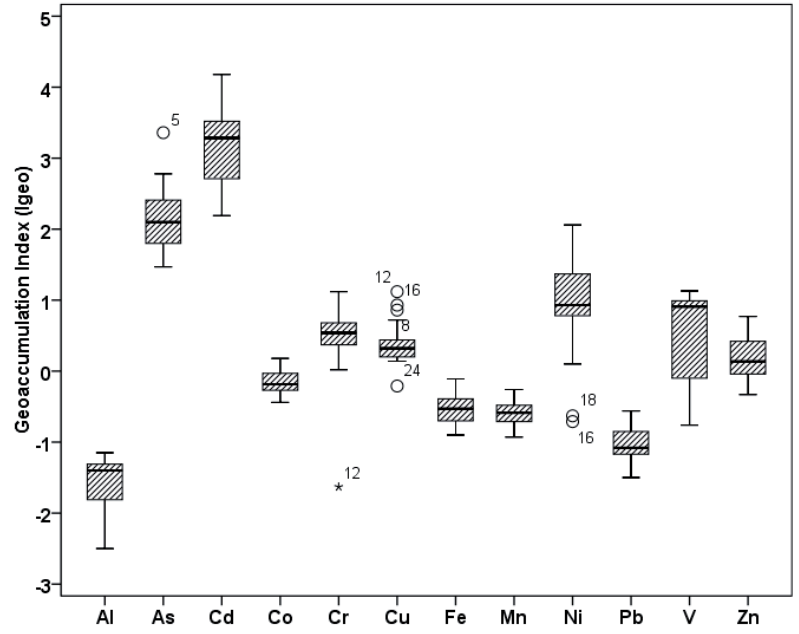

Fig. 3. Geo-accumulation index (Igeo) of heavy metals plotted in box and whisker method (rectangle-geo-accumulation index of metals; central line of each plot-median) of the surface sediments of Namal Lake.

for class 6 indicates 100-fold enrichment for metals with respect to reference values [54].

The geo-accumulation index for heavy metals is shown in Fig. 3 and Table 3. Igeo values in the studied area range -2.50 to -1.15 for $\mathrm{Al}, 1.47$ to 3.36 for $\mathrm{As}, 2.19$ to 4.18 for $\mathrm{Cd},-0.44$ to 0.0 .18 for $\mathrm{Co},-1.63$ to 1.12 for $\mathrm{Cr},-0.21$ to 1.12 for $\mathrm{Cu},-0.90$ to -0.11 for $\mathrm{Fe},-0.93$ to -0.26 for $\mathrm{Mn}$, -0.71 to 2.06 for $\mathrm{Ni},-0.1 .5$ to -0.56 for $\mathrm{Pb},-0.76$ to 1.13 for $\mathrm{V}$, and -0.33 to 0.77 for $\mathrm{Zn}$ (Table 3). The average values of Igeo of $\mathrm{Al}(-1.53)$, Co (-0.14), Fe (-0.55), Mn (-0.58), and $\mathrm{Pb}(-1.05)$ in the present investigation are found in class 0 (Igeo $\leq 0)$, indicating that they are unpolluted with respect to these elements in Namal Lake. However, the average values of $\mathrm{Cr}(0.47), \mathrm{Cu}(0.39), \mathrm{Ni}(0.92)$, and $\mathrm{Zn}$ $(0.19)$ are within class $1(0<$ Igeo $<1)$, representing the uncontaminated to moderately contaminated and acting as a normalizer in lake sediment. The highest average geo-accumulation index values for $\mathrm{As}$ (2.13) and Cd (3.09) indicate anthropogenic impact on Namal Lake sediments [55-56]. The accumulation of cadmium in the aquatic environment can be potentially harmful due to biological activities in sediment and health of aquatic environments [57]. Arsenic is another element that has significantly higher Igeo value due to anthropogenic and natural sources such as mining activities in surrounding areas, coal combustion, herbicides, and geogenics, and may pose a threat to aquatic environments. Unlike enrichment factors, the average values for Igeo are normally low and are found in the order: $\mathrm{Cd}(3.09)>\mathrm{As}(2.13)>\mathrm{Ni}(0.92$ )$>\mathrm{V}(0.54)>\mathrm{Cr}(0.47)>\mathrm{Cu}(0.39)>\mathrm{Zn}(0.19)>\mathrm{Co}(-0.14)>\mathrm{Mn}(-$ $0.58)>\mathrm{Fe}(-0.65)>\mathrm{Pb}(-1.05)>\mathrm{Al}(-1.53)$.

\section{Contamination Factor $(\mathrm{Cf})$ and Degree $(\mathrm{Cd})$}

Contamination factor is applied to evaluate sediment contamination by metal concentration [58]. It is a ratio of the metal concentration in sediment divided by the metal concentration in background value of upper continental crust (UCC):

$$
\mathrm{Cf}=\frac{\mathrm{Ci}}{\mathrm{Cn}}
$$

...where $\mathrm{Ci}$ is the concentration metal in sediment $\left(\mathrm{mg} \mathrm{kg}^{-1}\right)$ and $\mathrm{Cn}$ is the concentration of metal in background soil $\left(\mathrm{mg} \mathrm{kg}^{-1}\right)$. The classifications of contamination factors are as follows: $\mathrm{Cf}<1$ represents low contamination, $1<\mathrm{Cf}<3$ (moderate contamination), $3<\mathrm{Cf}<6$ (considerable contamination), and $\mathrm{Cf}>6$ (very high contamination) [12]. The degree of contamination is estimated based on the summation of the average contamination factors and calculated by the following equation.

$$
C d=\sum_{i=1}^{m=12} c f
$$

$\mathrm{Cd}$ is commonly used by numerous researchers as an indicator of contamination in sediments of aquatic environments [14, 59-60]. The contamination degree is defined as: $\mathrm{Cd}<5$, a low degree of contamination; $5<\mathrm{Cd}<10$, a moderate degree of contamination; $10<\mathrm{Cd}<15$, a considerable degree of contamination; and $\mathrm{Cd}>15$, a high degree of contamination [12]. The contamination factor of heavy metals in lake sediments is shown in Fig. 4 and Table 3. The range of contamination factors for Namal Lake sediments are: Al, 0.27-0.68 (0.53); As, 4.16-15.45 (6.90); Cd, 6.86-2725 (13.73); Co, 1.11-1.70 (1.37); Cr, 0.493.27 (2.16); $\mathrm{Cu}, 1.29-2.27$ (2.16); Fe, 0.78-1.39 (1.04); Mn, 0.78-1.2 (1.01); Ni 0.91-6.24 (3.08); Pb, 0.53-1.01 (0.73); V, 0.88-3.27 (2.38); and $\mathrm{Zn}, 1.19-2.56$ (1.75). In accordance with the adopted various classes, the average values of contamination factor are in the order of $\mathrm{Cd}>\mathrm{As}>\mathrm{Ni}>\mathrm{V}>\mathrm{Cr}$

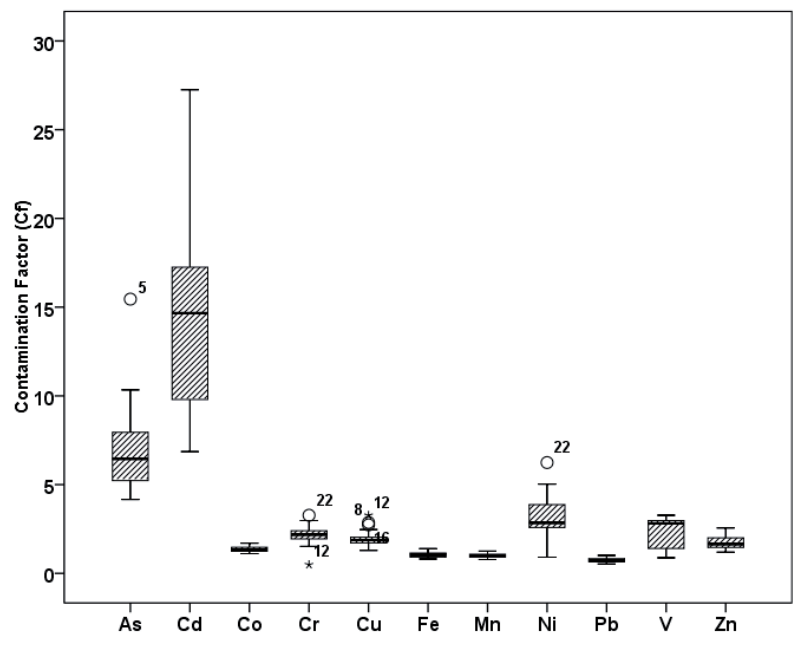

Fig. 4. Contamination factor (Cf) of heavy metals plotted in box and whisker method (rectangle-contamination factor of metals; central line of each plot-median) of the surface sediments of Namal Lake. 
$>\mathrm{Cu}>\mathrm{Zn}>\mathrm{Co}>\mathrm{Fe}>\mathrm{Mn}>\mathrm{Pb}>\mathrm{Al}$. Like enrichment factor and geo-accumulation index, the average contamination factor value for aluminum and lead represent low contamination $(\mathrm{C} f<1)$; copper, chromium, and vanadium in moderate contamination; nickel in considerable contamination; and arsenic and cadmium in very high contamination in Namal Lake sediments. The calculated Cd lies in range of 19.3 to 67.3 with average value of 36.7 , which indicate that certain sampling points in Namal sediments have a high degree of contamination.

\section{Pollution Load Index}

The pollution load index (PLI) is calculated as the nth root of $\mathrm{n}$ contamination factors (Cf) multiplied together by using the following equation:

$$
\mathrm{PLI}=\mathrm{n} \sqrt{\left(\mathrm{Cf} 1 \times \mathrm{Cf} 2 \times \mathrm{Cf} 3 \ldots \mathrm{Cf}_{\mathrm{n}}\right)}
$$

...where $\mathrm{Cf}$ is the contamination factor. The index can be used for assessing the level of metal pollution. The PLI value of $<1$ indicates no pollution while PLI $>1$ is polluted $[34,61]$. The variations in the intensity of pollution along the locations are determined with pollution load index. It is a quick tool for comparison of pollution status in various places. PLI in Namal sediments is shown in Fig. 5. It lies in range of 1.25 to 2.30 , with the highest value (2.30) at sampling sites (NL-8) indicating the most contaminated site in Namal (Fig. 5). The sampling sites with PLI values greater than one are polluted sites and suggest input of an anthropogenic source of pollution due to increased human activities [62]. However, the lowest PLI value is observed at sampling site (1.25). It is also observed that in general a decreasing pollution load index trend across Namal represents the dilution and dispersion of metals, and fluctuated randomly after sampling site NL-17 from source areas [63]. The lake receives water along with a substantial amount of disintegrated soil as runoff water from catchment areas and settles at the beginning of the lake, indicating elevated levels of pollution load on Namal. The contaminants may significantly affect sediment health.

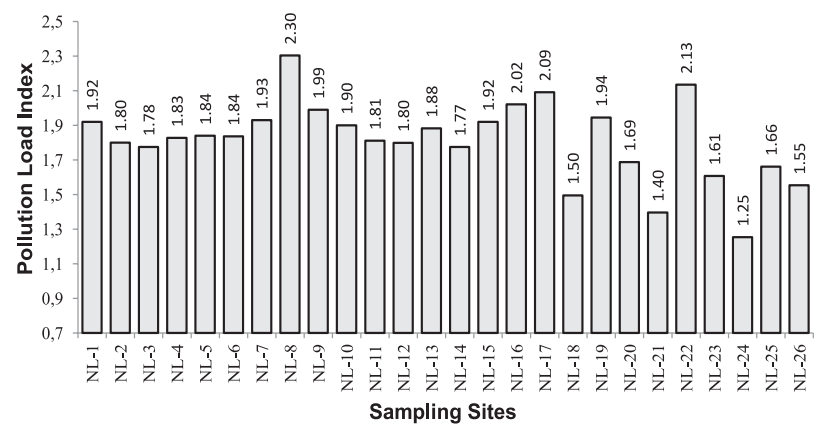

Fig. 5. Pollution load index of heavy metals in Namal Lake surface sediment.

\section{Potential Ecological Risk Index}

To achieve further understanding of heavy metals contamination in sediments, the potential ecological risk index (PERI) was determined to assess the risk of heavy metals. The potential ecological risk index [58, 64] is calculated by using the following equations.

$$
\text { Ecological Risk }\left(\mathrm{E}_{\mathrm{r}}\right)=\mathrm{Ti} \times \frac{\mathrm{Ci}}{\mathrm{Cn}}
$$

$$
\mathrm{RI}=\sum_{\mathrm{i}=1}^{\mathrm{n}=7}\left(\mathrm{Ti} \times \frac{\mathrm{Ci}}{\mathrm{C}}\right)
$$

...where $\mathrm{RI}$ is the risk index and $\mathrm{Ti}$ is the toxic response factor, e.g. $\mathrm{Cd}(30), \mathrm{As}(10), \mathrm{Cu}(5), \mathrm{Pb}(5), \mathrm{Cr}$ ( 2), $\mathrm{Zn}$ (1), and As (10) [65]. $\mathrm{C}_{\mathrm{i}}$ is the concentration of metal in the sample and $\mathrm{C}_{\mathrm{n}}$ is a reference value of upper continental crust. The ecological risk index is reported [66] as; $\mathrm{RI} \leq 150$, low potential ecological risk; $150<\mathrm{RI} \leq 300$, moderate ecological risk; $300<\mathrm{RI} \leq 600$, considerable potential ecological risk; and $\mathrm{RI}>600$, high potential ecological risk. Fig. 6 shows the contributions of different heavy metals to total ecological risk in sampling sites of Namal Lake. The risk index of heavy metals is in the range $\mathrm{Cd}$ (205.9-817.6), $\mathrm{Pb}$ (2.6-5.1), $\mathrm{Cu}$ (6.5-16.3), Ni (4.631.2), Cr (1.0-6.5), As (41.6-154.5), and Zn (1.2-2.6). In the studied area, $3.8 \%$ of sampling sites (NL-21) was within the limit (150-300) of moderate ecological risk, 61.5\% (16 locations) were within the limit (300-600) of considerable potential ecological risk, and $34.6 \%(\mathrm{RI}>600)$ were within the limit of high ecological risk from heavy metals pollution. The computed average risk index (RI) of a single metal in the studied area were in the order of $\mathrm{Cd}$ (411.9) $>\mathrm{As}(69.0)>\mathrm{Ni}(15.4)>\mathrm{Cu}(10.0)>\mathrm{Cr}(4.3)>\mathrm{Pb}(3.66)>$ $\mathrm{Zn}(1.7)$.

We observed that cadmium, arsenic, and nickel with significantly higher RI levels may pose high ecological risk to Namal Lake [39, 67]. The higher levels of cadmium and arsenic in sediment might due to the excessive use of phosphate fertilizer in agricultural fields and geogenic sources [68]. The potential ecological risk assessment of heavy metal pollution revealed that the Namal has been facing very serious heavy metal pollution, specifically with cadmium, arsenic, and nickel metals, and may pose a very high risk to the ecosystem $[1,69]$.

\section{Sediment Quality Guidelines}

Sediment quality guidelines (SQGs) provide tolerable concentrations of pollutants in sediments to protect living organisms present in sediment. The threshold effect levels (TELs) and probable effect levels (PELs) define three ranges for chemical concentrations, which are as follows: a) chemicals concentrations in sediments below TEL that are not related to adverse biological effects, b) 


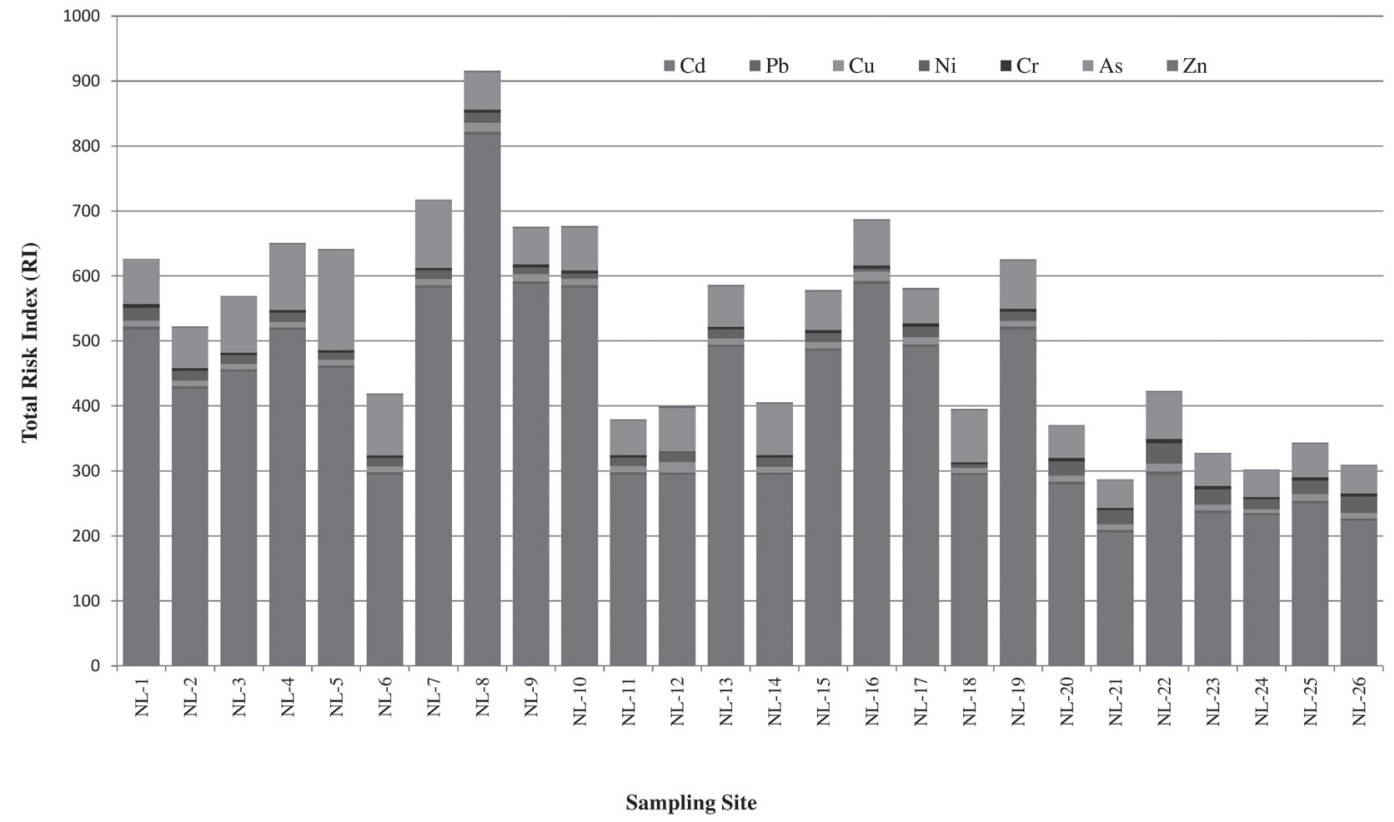

Fig. 6. Contributions of different heavy metals to total ecological risk in sampling sites of Namal Lake.

concentrations between TEL-PEL that can occasionally be associated with adverse biological effects, and c) content of chemicals exceeding the PEL that are expected to be frequently related to adverse biological effects [70-71].

In this study, freshwater sediment quality guidelines (TEL and PEL) [70] and the average concentrations of heavy metal (As, Cd, Cr, Cu, Ni, Pb, and Zn) in UCC [25] are used to compare with heavy metals concentrations in surface sediments, and data is presented in Table 4. The results indicate that there were $19.2 \%$ for $\mathrm{As}, 11.5 \%$ for $\mathrm{Cr}$, and $88.5 \%$ for Ni sampling sites in Namal Lake exceeding PEL, which suggests that As, $\mathrm{Cr}$, and $\mathrm{Ni}$ are associated with adverse biological effects on aquatic organisms and would occur frequently [39, 72-73]. Conversely, $80.8 \%$ of As, $100 \%$ of $\mathrm{Cd}, 84.62 \%$ of $\mathrm{Cr}, 88.46$ of $\mathrm{Cu}$, and $7.7 \%$ of $\mathrm{Ni}$ of sampling sites are found between two guidelines (TEL-PEL) and can occasionally be associated with adverse biological effects in Namal Lake. Among all sampling sites, only $3.85 \%$ of $\mathrm{Cr}, 11.5 \%$ of $\mathrm{Cu}, 3.4 \%$ of $\mathrm{Ni}, 100 \%$ of $\mathrm{Pb}$, and $100 \%$ of $\mathrm{Zn}$ samples in the studied area are below TEL and suggest that they would not be associated with adverse biological effects. From all heavy metals studied in this comparison, Ni contamination is highest and can frequently have adverse biological effects on benthic organisms. The higher value of $\mathrm{Ni}$ in sediments was also reported in sediments [42]. The heavy metals are also compared with average values of UCC. It is observed that all sampling sites $100 \%$ exceed these elements other than UCC values, except for $\mathrm{Cr}(96.2 \%), \mathrm{Pb}(3.85 \%)$, and $\mathrm{Ni}(92.3 \%)$. All these comparisons indicate that sediment can be occasionally responsible for adverse effects on organisms.

\section{Cluster Analysis}

Hierarchical cluster analysis (HCA) was performed on normalized data by using average linkage and

Table 4. Comparison of freshwater sediment quality guidelines (SQGs) with Namal Lake sediments ( $\left.\mathrm{mg} \mathrm{kg}^{-1}\right)$.

\begin{tabular}{|c|c|c|c|c|c|c|c|}
\hline & $\mathrm{As}$ & $\mathrm{Cd}$ & $\mathrm{Cr}$ & $\mathrm{Cu}$ & $\mathrm{Ni}$ & $\mathrm{Pb}$ & $\mathrm{Zn}$ \\
\hline Probable Effect Level (PEL) [70] & 17.0 & 3.5 & 90.0 & 196.6 & 35.9 & 91.3 & 315.0 \\
\hline Threshold Effect Level TEL) [70] & 5.9 & 0.6 & 37.3 & 35.7 & 18.0 & 35.0 & 123.1 \\
\hline Average Concentration in sediment & 13.8 & 1.4 & 75.6 & 28.6 & 57.0 & 12.4 & 90.9 \\
\hline Average Concentration of heavy metals in UCC [25] & 2 & 0.102 & 35 & 14.3 & 18.6 & 17 & 52 \\
\hline \% Sample Exceeded PEL (SQGs) & 19.2 & 0.0 & 11.5 & 0.0 & 88.5 & 0 & 0.0 \\
\hline \% Sample less than TEL (SQGs) & 0.0 & 0.0 & 3.85 & 11.5 & 3.8 & 100 & 100 \\
\hline \% Between TEL-PEL (SQGs) & 80.8 & 100 & 84.62 & 88.46 & 7.7 & 0 & 0 \\
\hline \% Exceeded from UCC & 100 & 100 & 96.16 & 100 & 92.31 & 3.85 & 100 \\
\hline
\end{tabular}




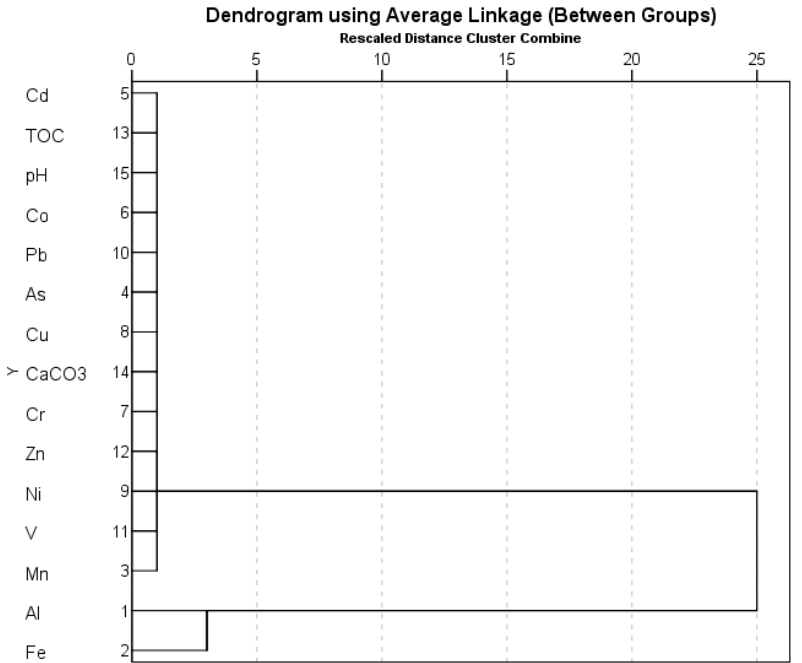

Fig. 7. Dendrogram of heavy metals, $\mathrm{pH}$, TOC, and $\mathrm{CaCO}_{3}$ within Namal Lake surface sediment using average linkage between groups.

squared Euclidean distance, which provides the extent of association of metals on their similarity between chemical properties [74-75]. Fig. 7 shows HCA (between groups) of metals within Namal surface sediment. In the present investigation, two clusters were identified from a dendrogram of geochemical data of Namal surface sediments with significant linkage distance [76]. Heavy metals within the same group may exhibit common anthropogenic or natural sources.

Group 1 includes $\mathrm{Al}$ and Fe with good similarity, which are basically natural geochemical elements associated with parent rock materials. Group II is constituted of $\mathrm{Cd}, \mathrm{TOC}, \mathrm{pH}, \mathrm{Co}, \mathrm{Pb}, \mathrm{As}, \mathrm{Cu}, \mathrm{CaCO}_{3}$, $\mathrm{Cr}, \mathrm{Zn}, \mathrm{Ni}, \mathrm{V}$, and $\mathrm{Mn}$, with strong similarity and significantly correlated with each other, and form a cluster associated with $\mathrm{Al}$ and $\mathrm{Fe}$ (Fig. 7) [30,77]. A lower cluster distance specifies a more significant association of metals [61]. $\mathrm{Ni}$ and $\mathrm{V}$ in the same group is also indicative of combustion for fossil fuel [78]. In addition, the significant contribution of agricultural waste, chemical fertilizer, and domestic waste into the study area enhanced the pollution levels.

\section{Multivariate Analysis}

\section{Principal Component Analysis}

PCA has been extensively used by numerous researchers to reduce variables of the contaminants and evaluate their sources [36, 79-80]. The PCA using varimax with Kaiser normalization is successfully applied on the entire geochemical data of 15 variables to identify the sources of heavy metals. Three factors from PCA are recalled with greater than one eigenvalues (Table 5). The total variance (geochemical parameters) of factors accounts for $76.136 \%$.
Table 5. Results of factor analysis of heavy metals, $\mathrm{pH}$, TOC, and $\mathrm{CaCO}_{3}$ in Namal Lake sediment.

\begin{tabular}{|c|c|c|c|}
\hline \multicolumn{4}{|c|}{ Rotated Component Matrix ${ }^{\mathrm{a}}$} \\
\hline & PC 1 & PC 2 & PC 3 \\
\hline $\mathrm{Al}$ & 0.587 & 0.756 & 0.017 \\
\hline $\mathrm{Fe}$ & 0.816 & -0.295 & 0.388 \\
\hline $\mathrm{Mn}$ & 0.883 & 0.040 & -0.076 \\
\hline As & -0.269 & 0.666 & 0.180 \\
\hline $\mathrm{Cd}$ & 0.462 & 0.656 & 0.179 \\
\hline Co & 0.950 & 0.047 & -0.008 \\
\hline $\mathrm{Cr}$ & 0.312 & -0.245 & 0.753 \\
\hline $\mathrm{Cu}$ & 0.856 & 0.172 & -0.137 \\
\hline $\mathrm{Ni}$ & 0.038 & -0.777 & 0.375 \\
\hline $\mathrm{Pb}$ & 0.489 & -0.254 & 0.570 \\
\hline $\mathrm{V}$ & 0.360 & 0.871 & -0.209 \\
\hline $\mathrm{Zn}$ & 0.862 & 0.328 & -.158 \\
\hline TOC & -0.336 & 0.324 & 0.696 \\
\hline $\mathrm{CaCO}_{3}$ & 0.423 & 0.069 & -0.763 \\
\hline $\mathrm{pH}$ & 0.018 & -0.719 & 0.106 \\
\hline Eigen Value & 5.632 & 3.652 & 2.137 \\
\hline$\%$ of Variance & 37.546 & 24.345 & 14.245 \\
\hline Cumulative \% Variance & 37.546 & 61.891 & 76.136 \\
\hline
\end{tabular}

Extraction method: principal component analysis

Rotation method: varimax with Kaiser normalization

a. Rotation converged in 10 iterations

Factor 1 (PC-1) accounting for $37.546 \%$ of the total variance, is categorized by high positive loadings of metals, which includes $\mathrm{Mn}(0.816), \mathrm{Co}(0.950), \mathrm{Cu}(0.856)$, and $\mathrm{Zn}(0.862)$, representing metals of the pollution group that are significantly associated with each other. However, moderate positive loading of Al (0.587) indicated relatively lower links. The high loading factors indicate natural and anthropogenic sources of pollution [12, 47]. The sources of contamination are mainly untreated domestic sewage, agricultural runoff, and natural minerals from weathering of rocks. Factor 2 (PC-2) accounts for $24.345 \%$ of the total variance and is categorized by high positive loadings of $\mathrm{Al}(0.756)$ and $\mathrm{V}$ (0.871), moderate loading of As (0.666) and Cd (0.656), and highly negative loading for $\mathrm{Ni}(-0.777)$ [48]. Similarly, factor 3 (PC-3) accounts for $14.245 \%$ of total variance that exhibit high positive loading of $\mathrm{Cr}(0.753)$ and TOC (0.996), high negative loading $\mathrm{CaCO}_{3}(-0.763)$, and moderate loading of $\mathrm{Pb}(0.570)$. Using the PCA technique, 15 variables were reduced to three independent factors. As a whole, PCA resolved high and moderate loading factors with positive and negative values showing the anthropogenic and natural sources of pollution [75, 81]. 
The classification of heavy metals with data of factors is consistent with cluster analysis.

\section{Conclusions}

The quantifications of heavy metals sources and their enrichment in lake sediments are extremely important environmental issues. The statistical data of heavy metals shows that $\mathrm{Fe}, \mathrm{As}, \mathrm{Cd}, \mathrm{Co}, \mathrm{Cr}, \mathrm{Cu}, \mathrm{Mn}, \mathrm{Ni}, \mathrm{Pb}, \mathrm{V}$, and $\mathrm{Zn}$ are higher than average values of the upper continental crust. The fluctuation in concentrations of heavy metals in the sediments suggests that the metals are influenced by anthropogenic inputs and geochemical processes. The heavy metal contaminations are assessed with EFs, Igeo, $\mathrm{Cf}$, and sediment quality guidelines. The results indicate that enrichment of metals in sediment is dominated by $\mathrm{Cd}, \mathrm{As}$, and $\mathrm{Ni}$, and to lesser extent by $\mathrm{Cr}, \mathrm{Cu}, \mathrm{Zn}$, and $\mathrm{V}$. Although the values of $\mathrm{Cf}$ showed the overall same trend as indicated by the EF, Igeo demonstrated the same behavior for As and Cd, but less for other studied metals. The ecological risk indicates that a $3.8 \%$ of sampling site NL-21 was within the limit (150-300) of moderate ecological risk, $61.5 \%$ of sampling sites were within the limit (300-600) of showing considerable potential ecological risk, and $34.6 \%$ of sampling sites (RI $>600)$ showed high ecological risk from heavy metals pollution. The sediment quality guidelines indicated that the majorities of sampling sites are contaminated with heavy metals (As, $\mathrm{Cd}, \mathrm{Cr}, \mathrm{Cu}$ and $\mathrm{Ni}$ ) and can occasionally be associated with adverse biological effects in Namal. The pollution load index and risk index indicates considerable risk to aquatic environments. Cluster analysis identified As and $\mathrm{Cd}$ due to their close relationship, and their occurrence can be related to the agricultural runoff in catchment areas and combustion of fossil fuel. PCA also was revealed as a tool to distinguish sources of heavy metal elements in lake sediment. The data generated in this study may be used in future for investigating and managing by decision-making authorities for the protection of freshwater lake/aquatic environments in Pakistan.

\section{Acknowledgements}

The authors wish to express their sincere gratitude to D.G. (PINSTECH), director of technology and head IAD for technical and field sampling support for completion of this study. The authors are indebted to two anonymous referees and to Polish Journal of Environmental Studies Executive Editor Hanna Radecka and Editor-in-Chief Jerzy Radecki for their useful comments and suggestions. The authors recognize the services of Dr. Muhammad Bashir, deputy chief scientist for provision of analytical facility at CAFD for ICP-OES. Thanks are also due to Mr. Sajjad Munir, Dr. Nadeem Yaqoob, Dr. Um-e-Robab, Dr. Jawaria Abid, Dr. Muhammad Zaman, Dr. Tanvir Ahmad, and Dr. Naeem Abassi for providing assistance.

\section{References}

1. YAN N., LIU W., XIE H., GAO L., HAN Y., WANG M., LI H. Distribution and assessment of heavy metals in the surface sediment of Yellow River, China. Journal of Environmental Sciences, 39, 45, 2016.

2. SALATI S., MOORE F. Assessment of heavy metal concentration in the Khoshk River water and sediment, Shiraz, Southwest Iran. Environmental Monitoring and Assessment, 164 (1-4), 677, 2010.

3. RUILIAN Y., XING Y., YUANHUI Z., GONGREN H., XIANGLIN T. Heavy metal pollution in intertidal sediments from Quanzhou Bay, China. Journal of Environmental Sciences, 20, 664, 2008.

4. SEKABIRA K., ORIGA H.O., BASAMBA T.A., MUTUMBA G., KAKUDIDI E. Assessment of heavy metal pollution in the urban stream sediments and its tributaries. International Journal of Environmental Science and Technology, 7 (3), 435, 2010.

5. DASSENAKIS M., ANDRIANOS H., DEPIAZI G., KONSTANTAS A., KARABELA M., SAKELLARI A., SCOULLOS M. The use of various methods for the study of metal pollution in marine sediments, the case of Euvoikos Gulf, Greece. Applied Geochemistry, 18, 781, 2003.

6. GOHER M.E., FARHAT H.I., ABDO M.H., SALEM S.G. Metal pollution assessment in the surface sediment of Lake Nasser, Egypt. Egyptian Journal of Aquatic Research, 40, 213, 2014.

7. FENG H., HAN X., ZHANG W., YU L. A preliminary study of heavy metal contamination in Yangtze River intertidal zone due to urbanization. Marine Pollution Bulletin, 49 (1112), 910, 2004

8. DU LAING G., VANTHUYNE D., TACK F.M.G., VERLOO M. G. Factors affecting metal mobility and bioavailability in the superficial intertidal sediment layer of the Scheldt Estuary. Aquatic Ecosystem Health and Management, 10 (1), 33, 2007.

9. GROSHEVA E.L., VORONSKAYA G.N., PASTUKHOVE M.V. Trace element bio-availability in Lake Baikal. Aquatic Ecosystem Health and Management, 3 (2), 229, 2000.

10. SOARES H.M.V.M., BOAVENTURA R.A.R., MACHADO A.A.S.C., ESTEVES DA SILVA J.C.G. Sediments as monitors of heavy metal contamination in Ave river basin (Portugal), Multivariate analysis of data. Environmental Pollution, 105, 311, 1999.

11. GARRETT R.G. Natural sources of metals to the environment. Human and Ecological Risk Assessment, 6, 945, 2000.

12. GHADIMI F. Assessment of the sources of chemical elements in sediment from Arak Mighan Lake. International Journal of Sediment Research, 29, 159, 2014.

13. LIU E., SHEN J., YANG L., ZHANG E., MENG X., WANG J. Assessment of heavy metal contamination in the sediments of Nansihu Lake Catchment, China. Environmental Monitoring and Assessment, 161, 217, 2010.

14. SMUC N.R., SERAFIMOVSKI T., DOLENEC T., DOLENEC M., VRHOVNIK P., VRABEC M., JAČIMOVIĆ R., ZORN V.L., KOMAR D. Mineralogical and geochemical study of Lake Dojran sediments (Republic of Macedonia). Journal of Geochemical Exploration, 150, 73, 2015.

15. EL-SAYED S.A., MOUSSA E.M.M., EL-SABAGH M. E. I. Evaluation of heavy metal content in Qaroun Lake, El-Fayoum, Egypt. Part I: Bottom sediments. Journal of Radiation Research and Applied Sciences, 8, 276, 2015. 
16. KISHE M.A., MACHIWA J.F. Distribution of heavy metals in sediments of Mwanza Gulf of Lake Victoria. Environment International, 28, 619, 2013.

17. HOU D., HE J., LÜ C., REN L., FAN Q., WANG J., XIE $Z$. Distribution characteristics and potential ecological risk assessment of heavy metals $(\mathrm{Cu}, \mathrm{Pb}, \mathrm{Zn}, \mathrm{Cd})$ in water and sediments from lake Dalinouer, China. Ecotoxicology and Environmental Safety, 93, 135, 2013.

18. RATHEESH KUMAR C.S., JOSEPH M.M., GIREESH KUMAR T.R., RENJITH K.R., MANJU M.N., CHANDRAMOHANAKUMAR N. Spatial variability and contamination of heavy metals in the inter-tidal systems of a tropical environment. International Journal of Environmental Research, 4 (4), 691, 2010.

19. KHAN M.S., AADIL N., GILLANI S.T.A. Effects of human activities on eco-system of Kallar Kahar, Namal and Khan Pur lakes in Pakistan, Hydro-Eco, Hydrology and Ecology: Ecosystems, Groundwater and Surface WaterPressures and Options, Abstract number 327, Vienna, Austria, 2011.

20. ENVIRONMETAL PROTECTION AGENCY. Methods for collection, storage and manipulation of sediments for chemical and toxicological analyses. Technical Manual, EPA-823-B-01-002, 2001.

21. NAVARRO E.M.G., TAGLE M.E.V., MARÍN M.T.L., ALFONSO M.S.P. Comparison of USEPA 3050B and ISO 14869-1:2001 digestion methods for sediment analysis by using FAAS and ICP-OES Quantification Techniques. Quim. Nova, 34 (8), 1443, 2011.

22. LAZĂR L., GOMOIU M.-T., BOICENCO L., VASILIU D. Total organic carbon (TOC) of the surface layer sediments covering the seafloor of the Romanian Black Sea Coast. Geo-Eco-Marina, 18, 121, 2012.

23. JEYABAL G., RAMASAMY S. Down core variation in sediment characteristics and trace element geochemistry of a core sample in Pichavaram Mangrove area, Tamil Nadu, Southeast Coast of India. EnviroGeoChimicaActa, 1 (3), 206, 2014.

24. WALI A., COLINET G., KSIBI M. Speciation of heavy metals by modified BCR sequential extraction in soils contaminated by phosphogypsum in Sfax, Tunisia. Environmental Research, Engineering and Management, 4 (70), 14, 2014.

25. WEDEPOHL K.H. The composition of the continental crust. Geochim Cosmochim Acta, 59, 1217, 1995.

26. GAO X., LI P. Concentration and fractionation of trace metals in surface sediments of intertidal Bohai Bay, China. Marine Pollution Bulletin, 64 (8), 1529, 2012.

27. BO L., WANG D., LI T., LI Y., ZHANG G., WANG C., ZHANG S. Accumulation and risk assessment of heavy metals in water, sediments, and aquatic organisms in rural rivers in the Taihu Lake region, China. Environmental Science and Pollution Research, 22, 6721, 2015.

28. VEMIC M., ROUSSEAU D., DU LAING G., LENS P. Distribution and fate of metals in the Montenegrin part of Lake Skadar. International Journal of Sediment Research, 29, 357, 2014

29. ANSARI Z.A., INGOLE B.S., ABIDI S.A.H. Organic enrichment and Benthic fauna-Some Ecological consideration. Indian Journal of Geo-Marine Sciences, 43 (4), 554, 2014.

30. SKORDAS K., KELEPERTZIS E., KOSMIDIS D., PANAGIOTAKI P., VAFIDIS D. Assessment of nutrients and heavy metals in the surface sediments of the artificially lake water reservoir Karla, Thessaly, Greece. Environmental Earth Sciences, 73, 4483, 2015.
31. ARSHAD M. Site management plan, Kallar Kahar Game Reserve, WWF, Wetlands, The Ministry of Environment's Pakistan Wetlands Programme, Report, 10, 2011.

32. BAM E.K.P., AKITI T.T., OSAE S.D., GANYAGLO S.Y., GIBRILLA A. Multivariate cluster analysis of some major and trace elements distribution in an unsaturated zone profile, Densu river basin, Ghana. African Journal of Environmental Science and Technology, 5 (3), 155,2011

33. VRHOVNIK P., ŠMUC N.R., DOLENEC T., SERAFIMOVSKI T., DOLENEC M. An evaluation of trace metal distribution and environmental risk in sediments from the Lake Kalimanci (FYR Macedonia). Environmental Earth Sciences, 70 (2), 761, 2013.

34. KHAN M.Z.H., HASAN M.R., KHAN M., AKTAR S., FATEMA K. Distribution of heavy metals in surface sediments of the Bay of Bengal Coast. Journal of Toxicology, 2017, 1, 2017.

35. MA L., WU J., ABUDUWAILI J., LIU W. Geochemical responses to anthropogenic and natural influences in Ebinur Lake sediments of arid Northwest China. PLOS ONE, 1, 2016.

36. YALCIN F., KILIC S., NYAMSARI D.G., YALCIN M.G., KILIC M. Principal component analysis of integrated metal concentrations of Bogacayi Riverbank Sediments in Turkey. Polish Journal of Environmental Studies, 25 (2), 471, 2016.

37. YALCIN F., NYAMSARI D.G., PAKSU E., YACIN M.G. Statistical assessment of heavy metal distribution and contamination of beach sands of Antalya-Turkey: An approach to the multivariate analysis technique. Filomat, 30 (4), 945, 2016.

38. PARAMASIVAM K., RAMASAMY V., SURESH G. Impact of sediment characteristics on the heavy metal concentration and their ecological risk level of surface sediments of Vaigai river, Tamilnadu, India. Spectrochimica Acta, Part A: Molecular and Biomolecular Spectroscopy. 137, 397, 2015.

39. NIU Y., JIAO W., YU H., NIU Y., PANG Y., XU X., GUO $X$. Spatial evaluation of heavy metals concentrations in the surface sediment of Taihu Lake. International Journal of Environmental Research and Public Health, 12, 15028, 2015.

40. PALMA P., LEDO L., ALVARENGA P. Assessment of trace element pollution and its environmental risk to freshwater sediments influenced by anthropogenic contributions: The case study of Alqueva reservoir (Guadiana Basin). Catena, 128, 174, 2015.

41. MOHIUDDIN K.M., ZAKIR H.M., OTOMO K., SHARMIN S., SHIKAZONO N. Geochemical distribution of trace metal pollutants in water and sediments of downstream of an urban river. International Journal of Environmental Science and Technology, 7 (1), 17, 2010.

42. XU L., LI J. Speciation and degrees of contamination of metals in sediments from upstream and downstream reaches along the catchment of the Southern Bohai Sea, China. International Journal of Environmental Research and Public Health, 12, 7959, 2015.

43. BAI J., CUI B., CHEN B., ZHANG K., DENG W., GAO H. Xiao R. Spatial distribution and ecological risk assessment of heavy metals in surface sediments from a typical plateau lake wetland, China. Ecological Modelling, 222, 301, 2011.

44. OTARI M., DABIRI R. Geochemical and environmental assessment of heavy metals in soils and sediments of Forumad Chromite mine, NE of Iran. Journal of Mining and Environment, 6 (2), 251, 2015. 
45. SHAARI H., AZMI S.N.H.M., SULTAN K., BIDAI J., MOHAMAD Y. Spatial distribution of selected heavy metals in surface sediments of the EEZ of the East Coast of Peninsular Malaysia. International Journal of Oceanography, 2015, 1, 2015.

46. JING-JUN L., YING L. Study on heavy metal and ecological risk assessment from Gansu, Ningxia and Inner Mongolia sections of the Yellow, China. Spectroscopy and Spectral Analysis. 33 (12), 3249, 2013.

47. ZENG H., WU J. Heavy metal pollution of lakes along the Mid-Lower Reaches of the Yangtze River in China: Intensity, sources and spatial patterns. International Journal of Environmental Research and Public Health, 10, 793, 2013.

48. VAROL M. Assessment of heavy metal contamination in sediments of the Tigris River (Turkey) using pollution indices and multivariate statistical techniques. Journal of Hazardous Materials, 195, 355, 2011.

49. BIRCH G. A scheme for assessing human impacts on coastal aquatic environment using sediments. In: Wollongong CD. University Papers in Center for Maritime Policy, 14, Australia, 2003.

50. DELGADO J., NIETO J.M., BOSKI T. Analysis of the spatial variation of heavy metals in the Guadiana Estuary sediments (SW Iberian Peninsula) based on GIS-mapping techniques. Estuarine Coastal and Shelf Science, 88 (1), 71, 2010.

51. UWAH I.E., DAN S.F., ETIUMA R.A., UMOH U.E. Evaluation of status of heavy metals pollution of sediments in Qua-Iboe River Estuary and associated Creeks, SouthEastern Nigeria. Environment and Pollution, 2 (4), 110, 2013.

52. NOWROUZI M., POURKHABBAZ A. Application of geo accumulation index and enrichment factor for assessing metal contamination in the sediments of Hara Biosphere Reserve, Iran. Chemical Speciation and Bioavailability, 26 (2), 99, 2014.

53. KABIR M.I. LEE H., KIM G., JUN T. Correlation assessment and monitoring of the potential pollutants in the surface sediments of Pyeongchang River, Korea. International Journal of Sediment Research, 26, 152, 2011.

54. HARIKUMAR P.S., JISHA T.S. Distribution pattern of trace metal pollutants in the sediments of an urban wetlands in the southwest coast of India. International Journal of Engineering Science and Technology, 2 (5), 840, 2010.

55. DOU Y., LI J., ZHO J., HU B., YANG S. Distribution, enrichment and source of heavy metals in surface sediments of the Eastern Beibu Bay, South China Sea. Marine Pollution Bulletin, 67, 137, 2013.

56. JING L. Risk assessment of heavy metals in surface sediments from the Yanghe River, China. International Journal of Environmental Research and Public Health, 11, 12441, 2014.

57. RZĘTAŁA M.A. Cadmium contamination of sediments in the water reservoirs in Silesian Upland (southern Poland). Journal of Soils and Sediments, 16, 2458, 2016.

58. BANU Z., CHOWDHURY S.A., HOSSAIN D., NAKAGAMI K. Contamination and ecological risk assessment of heavy metal in the sediment of Turag River, Bangladesh: An index analysis approach. Journal of Water Resource and Protection, 5, 239, 2013.

59. IQBAL J., SHAH M.H., AKHTER G. Characterization, source apportionment and health risk assessment of trace metals in freshwater Rawal Lake, Pakistan. Journal of Geochemical Exploration, 125, 94, 2013.
60. ZAHRA A., HASHMI M.Z., MALIK R.N., AHMED Z. Enrichment and geo-accumulation of heavy metals and risk assessment of sediments of the Kurang Nallah, feeding tributary of the Rawal lake, reservoir, Pakistan. Science of the Total Environment, 470-471, 925, 2014.

61. KRIKA A., KRIKA F. Evaluation of the status of heavy metal pollution in surface water and sediments of the Nil River (North Eastern Algeria). Pollution, 3 (2), 301, 2017.

62. MMOLAWA K.B., LIKUKU A.S., GABOUTLOELOE G.K. Assessment of heavy metal pollution in soils along major roadside areas in Botswana. African Journal of Environmental Science and Technology, 5 (3), 186, 2011.

63. CHAKRAVARTY M., PATIGIRI A.D. Metal Pollution Assessment in Sediments of the Dikrong River, N.E. India. Journal of Human Ecology, 27 (1), 63, 2009.

64. SAEEDI M., LI L.Y., SALMANZADEH M. Heavy metals and polycyclic aromatic hydrocarbons: Pollution and ecological risk assessment in street dust of Tehran. Journal of Hazardous Materials, 227-228, 9, 2012.

65. SWARNALATHA K., LETHA J., AYOOB S. Ecological risk assessment of a tropical lake system. Journal of Urban and Environmental Engineering, 7 (2), 323, 2013.

66. LIU J., ZHUO Z., SUN S., NING X., ZHAO S., XIE W., WANG Y., ZENG L., HUANG R., LI B. Concentrations of heavy metals in six municipal sludges from Guangzhou and their potential ecological risk assessment for agricultural land use. Polish Journal of Environmental Studies, 24 (1), $165,2015$.

67. NTAKIRUTIMANA T., DU G., GUO J.-S., GAO X., HUANG L. Pollution and potential ecological risk assessment of heavy metals in a Lake. Polish Journal of Environmental Studies, 22 (4), 1129, 2013.

68. YISA J., JACOB J.O., ONOYIMA C.C. Identification of sources of heavy metals pollution in road deposited sediments using multivariate statistical analysis. Journal of Emerging Trends in Engineering and Applied Sciences, 2 (4), 658, 2011.

69. ÇIÇEK A., TOKATLI C., KÖSE E. Ecological risk assessment of heavy metals in sediment of Felent Stream, Sakarya River Basin, Turkey. Pakistan Journal of Zoology, 45 (5), 1335, 2013.

70. MACDONALD D.D., INGERSOLL C.G., BERGER T. A. Development and evaluation of consensus-based sediment quality guidelines for freshwater ecosystems. Archive of Environmental Contamination and Toxicology, 39, 20, 2000.

71. SALEEM M., IQBAL J., SHAH M.H. A study of seasonal variations and risk assessment of selected metals in sediments from Mangla Lake, Pakistan. Journal of Geochemical Exploration, 125, 144, 2013.

72. XU L., LI J. Speciation and degrees of contamination of metals in sediments from upstream and downstream reaches along the catchment of the Southern Bohai Sea, China. International Journal of Environmental Research and Public Health, 12 (7), 7959, 2015.

73. HO H.H., SWENNEN R., VAN DAMME A. Distribution and contamination status of heavy metals in estuarine sediments near Cua Ong Harbor, Ha Long Bay, Vietnam. Geologica Belgica, 13 (1-2), 37, 2010.

74. IBRAHIM A., JUAHIR H., TORIMAN M. E., MUSTAPHA A., AZID A., ISIYAKA H. A. Assessment of surface water quality using multivariate statistical techniques in the Terengganu River Basin. Malaysian Journal of Analytical Sciences, 19 (2), 338, 2015.

75. IGNATAVIČIUS G., VALSKYS V., BULSKAYA I., PALIULIS D., ZIGMONTIENĖC A., SATKŪNAS J. 
Heavy metal contamination in surface runoff sediments of the urban area of Vilnius, Lithuania. Estonian Journal of Earth Sciences, 66 (1), 13, 2017.

76. YISA J., JACOB, J.O., ONOYIMA C.C. Assessment of toxic levels of some heavy metals in road deposited sediments in Suleja, Nigeria. American Journal of Chemistry, 2 (2), 34, 2012.

77. FU J., ZHAO C., LUO Y., LIU C., KYZAS G.Z., LUO Y., ZHAO D., AN S., ZHU H. Heavy metals in surface sediments of the Jialu River, China: Their relations to environmental factors. Journal of Hazardous Materials, 270, 102, 2014

78. ZHANG H., WANG Z., ZHANG Y., HU Z. The effects of the Qinghai-Tibet railway on heavy metals enrichment in soils. Science of the Total Environment, 439, 240, 2012.
79. REN J., SHANG Z., TAO L., WANG X. Multivariate analysis and heavy metals pollution evaluation in Yellow River surface sediments. Polish Journal of Environmental Studies, 24 (3), 1041, 2015.

80. ILIE M., MARINESCU F., ANGHEL A.-M., GHIȚĂ G., DEÁK G., RAISCHI M., CIRSTINOIU C., MATEI M., ZAMFIR S. Spatial distribution of heavy metal contamination in surface sediments from the Danube River. International Journal of Environmental Sciences, 1, 230, 2016.

81. HU C., DENG, Z.-M., XIE Y.-H., CHEN X.-S., LI, F. The risk assessment of sediment heavy metal pollution in the East Dongting Lake Wetland. Journal of Chemistry, 1-8, 2015. 